OPEN ACCESS

Edited by:

Abele Donati,

Marche Polytechnic University, Italy

Reviewed by:

Elisa Damiani,

Marche Polytechnic University, Italy Ivana Budic,

University of Niš, Serbia

*Correspondence:

Christopher M. Horvat christopher.horvat@chp.edu

Specialty section

This article was submitted to Intensive Care Medicine and Anesthesiology,

a section of the journal

Frontiers in Medicine

Received: 02 March 2021 Accepted: 27 April 2021 Published: 07 June 2021

Citation:

Pelletier JH, Ramgopal S and Horvat CM (2021) Hyperoxemia Is Associated With Mortality in Critically III Children. Front. Med. 8:675293. doi: 10.3389/fmed.2021.675293

\section{Hyperoxemia Is Associated With Mortality in Critically III Children}

\author{
Jonathan H. Pelletier ${ }^{1}$, Sriram Ramgopal ${ }^{2}$ and Christopher M. Horvat ${ }^{1,3 *}$ \\ ${ }^{1}$ Division of Pediatric Critical Care Medicine, Department of Critical Care Medicine, UPMC Children's Hospital of Pittsburgh, \\ Pittsburgh, PA, United States, ${ }^{2}$ Department of Pediatrics, Ann and Robert H. Lurie Children's Hospital of Chicago, \\ Northwestern University Feinberg School of Medicine, Chicago, IL, United States, ${ }^{3}$ Division of Health Informatics, \\ Department of Pediatrics, UPMC Children's Hospital of Pittsburgh, Pittsburgh, PA, United States
}

Multiple studies among adults have suggested a non-linear relationship between arterial partial pressure of oxygen $\left(\mathrm{PaO}_{2}\right)$ and clinical outcomes. Meta-analyses in this population suggest that high levels of supplemental oxygen resulting in hyperoxia are associated with mortality. This mini-review focuses on the non-neonatal pediatric literature examining the relationship between $\mathrm{PaO}_{2}$ and mortality. While only one pilot pediatric randomized-controlled trials exists, over the past decade, there have been at least eleven observational studies examining the relationship between $\mathrm{PaO}_{2}$ values and mortality in critically ill children. These analyses of mixed-case pediatric ICU populations have generally reported a parabolic ("u-shaped") relationship between $\mathrm{PaO}_{2}$ and mortality, similar to that seen in the adult literature. However, the estimates of the point at which hyperoxemia becomes deleterious have varied widely $(300-550 \mathrm{mmHg}$ ). Where attempted, this effect has been robust to analyses restricted to the first $\mathrm{PaO}_{2}$ value obtained, those obtained within $24 \mathrm{~h}$ of admission, anytime during admission, and the number of hyperoxemic blood gases over time. These findings have also been noted when using various methods of risk-adjustment (accounting for severity of illness scores or complex chronic conditions). Similar relationships were found in the majority of studies restricted to patients undergoing care after cardiac arrest. Taken together, the majority of the literature suggests that there is a robust parabolic relationship between $\mathrm{PaO}_{2}$ and risk-adjusted pediatric ICU mortality, but that the exact threshold at which hyperoxemia becomes deleterious is unclear, and likely beyond the typical target value for most clinical indications. Findings suggest that clinicians should remain judicious and thoughtful in the use of supplemental oxygen therapy in critically ill children.

Keywords: oxygen, critically ill children, hyperoxaemia, mortality, review

\section{INTRODUCTION}

Therapeutic oxygen administration has been studied since the early 1900s (1). Oxygen therapy has expanded dramatically in the last century. Today, many hospitalized patients and the majority of intensive care patients receive some form of supplemental oxygen $(2,3)$. Though the link between hyperoxia (supranormal oxygen delivery) and mortality was documented as early as the 1780s (4), there has been increasing interest in understanding this relationship in the past two decades. The association between hyperoxemia (supranormal blood oxygen content) 
and poor outcomes was first described among critically ill neonates in the 1990s $(5,6)$, culminating in recommendations to provide room air concentration oxygen to critically ill neonates in national guidelines (7). These findings prompted further research to evaluate the potential adverse effects of high oxygen concentration in other populations; initially adults, and more recently, among pediatric patients. In this review, we summarize recent findings with respect to the association between hyperoxemia and outcomes in critically ill pediatric patients. For an in-depth review of oxygen physiology in premature infants and in the delivery room, the reader is directed elsewhere (8-12).

\section{MECHANISMS OF OXYGEN TOXICITY}

A number of reasons have been postulated to account for the potential toxicity of supranormal partial pressures of oxygen $(4,13)$. Mammalian cells depend upon mitochondria to generate adenosine triphosphate using aerobic metabolism (14). This process always generates small amounts of reactive oxygen species (ROS) (14). Normal intracellular signaling depends upon a balance of ROS generation and scavenging by enzymes such as superoxide dismutase $(15,16)$. When scavenging mechanisms are overwhelmed, ROS cause DNA damage, protein denaturation, and cell membrane damage (lipid peroxidation) $(4,15,17,18)$. High fractions of inspired oxygen $\left(\mathrm{FiO}_{2}\right)$, particularly $\geq 0.6$, have been found to cause alveolar mitochondria to generate an excess of reactive oxygen species, overwhelming normal scavenging mechanisms, and leading to cell death $(4,15,17,18)$. In addition to acting as direct cellular toxins, ROS also trigger proinflammatory signal cascades, neutrophil and macrophage recruitment, and platelet aggregation $(4,19)$.

Adults predominantly suffer acute lung injury secondary to hyperoxia $(4,19)$. By contrast, the premature and newborn population appears to be especially vulnerable to the multisystem effects of hyperoxia due to poorly developed ROS scavenging mechanisms (10). In this population, hyperoxia has been associated with retinopathy (20), intraventricular hemorrhage $(10,21)$, necrotizing enterocolitis $(21)$, and cancers (particularly leukemia) $(22,23)$.

\section{BRIEF REVIEW OF PIVOTAL ADULT STUDIES}

Prior studies in adults have consistently suggested that an arterial partial pressure of oxygen $\left(\mathrm{PaO}_{2}\right) \geq 300 \mathrm{mmHg}$ (hyperoxemia) is associated with poorer survival (24-26) and neurologic outcome (27) following cardiac arrest. One recent meta-analysis, summarizing results from 25 randomized controlled studies with $>16,000$ patients having a variety of critical illnesses suggested a liberal oxygen strategy was associated with a higher relative risk of mortality, both at 30-days and at longest follow up, supporting a conservative approach in the use of supplemental oxygen (28). However, only $2 / 25$ of the original studies included in this analysis showed significant benefit associated with a conservative oxygen strategy $(29,30)$.
To date, one pilot study and two full randomized controlled trials have evaluated conservative vs. liberal oxygen therapy in mixed-diagnosis critically ill adult populations (30-32). These trials came to conflicting conclusions. A single-center, openlabel trial randomized 434 critically ill mechanically ventilated adults to target $\mathrm{PaO}_{2} 70-100 \mathrm{mmHg}$ and oxygen saturation $\left(\mathrm{SpO}_{2}\right)$ 94-98\% vs. $\mathrm{PaO}_{2} \leq 150 \mathrm{mmHg}$ and $\mathrm{SpO}_{2} \geq 97 \%$ (30). This study showed a $42.6 \%$ reduction in all-cause ICU mortality ( 11.6 vs. $20.2 \%$ in the conservative vs. liberal groups, respectively, $p=0.01$ ), as well as lower incidences of shock, liver failure, and bacteremia (30). However, this trial excluded patients with exacerbations of chronic obstructive pulmonary disease, and was terminated early due to an earthquake, resulting in a reduction of the sample size to $72.7 \%$ of the target (30). A pilot study examined $\mathrm{SpO}_{2}$ targets of $88-92 \%$ vs. $\geq 96 \%$ in 102 critically ill adults (31). They found non-significant decreases in 90 day mortality in the conservative oxygen therapy group, with a hazard ratio of 0.77 (95\% CI, $0.40-1.50 ; P=0.44)$, and a hazard ratio of 0.49 (95\% CI, 0.20-1.17; $P=0.10$ ) in patients with $\mathrm{PaO}_{2} / \mathrm{FiO}_{2}$ ratio $<300$ (31). A subsequent full randomized controlled trial did not show benefit (32). This trial analyzed 965 critically ill adults randomized to receive "usual care" (where the lower $\mathrm{SpO}_{2}$ goal was set by the clinician, and there was no upper $\mathrm{SpO}_{2}$ goal) or "conservative oxygen therapy" (where the lower $\mathrm{SpO}_{2}$ goal was set by the clinician, but $\mathrm{FiO}_{2}$ was actively weaned for $\mathrm{SpO}_{2}$ $\geq 97 \%$ ) with a primary outcome of number of ventilator free days by day 28 (32). This trial found no significant difference in ventilator free days, or the secondary outcomes of 90 -day or 180day mortality (32). However, only 138/965 (14.3\%) of included patients had primary respiratory diagnoses, and the difference between mean $\mathrm{FiO}_{2}$ and $\mathrm{PaO}_{2}$ between the groups was very small (32). After the first day, both groups had mean $\mathrm{FiO}_{2}$ values $\leq 0.37$ and mean $\mathrm{PaO}_{2}$ values $\leq 100 \mathrm{mmHg}$ (32).

Taken together, these data suggest that extreme hyperoxemia is associated with worse outcomes, though the exact threshold for harm is uncertain. Similarly, it is unclear which has a greater impact: a high $\mathrm{FiO}_{2}$ or high $\mathrm{PaO}_{2}$. Regardless, and perhaps because of the conflicting evidence, clinicians are generally less attentive to hyperoxemia than to hypoxemia (33-35), causing patients to be exposed to higher $\mathrm{FiO}_{2}$ than needed.

\section{REVIEW OF PEDIATRIC LITERATURE}

In the past decade, there have been 12 pediatric studies, encompassing a total of 26,838 pediatric ICU admissions, evaluating the association between $\mathrm{PaO}_{2}$ and mortality [Table 1; $(36-47)]$. While the results of individual studies vary, several studies have identified a second-order polynomial ("u-shaped") relationship between $\mathrm{PaO}_{2}$ and mortality among critically ill children $(36,37,41,47)$. These studies can generally be grouped according to their included population.

\section{Pediatric ICU Patients With Heterogenous Diagnoses}

Six of the twelve studies considered heterogenous patients admitted to the pediatric ICU (36-41). Of these, four 
TABLE 1 | Summary of pediatric studies examining the relationship between $\mathrm{PaO}_{2}$ and mortality.

\begin{tabular}{|c|c|c|c|c|c|c|c|}
\hline References & Study type & Population & Number & Predictor & Outcome & Analysis & Key findings \\
\hline \multicolumn{8}{|l|}{ All diagnoses } \\
\hline Raman et al. (36) & $\begin{array}{l}\text { Retrospective, } \\
\text { observational }\end{array}$ & Single-center PICU & 7,410 admissions & $\begin{array}{l}\text { Admission hyperoxemia } \\
\text { (>300 mmHg) and hypoxia } \\
\text { (<60 mmHg) }\end{array}$ & $\begin{array}{l}\text { In-hospital } \\
\text { mortality }\end{array}$ & $\begin{array}{l}\text { Polynomial regression } \\
\text { with modified PIM-2 } \\
\text { risk-adjustment, age } \\
\text { and gender }\end{array}$ & $\begin{array}{l}\text { U-shaped association between } \mathrm{PaO}_{2} \\
\text { and mortality } \\
\text { Modified standardized mortality ratio } \\
1.34 \text { for hypoxemia, and } 0.83 \\
\text { for hyperoxemia }\end{array}$ \\
\hline Numa et al. (37) & $\begin{array}{l}\text { Retrospective, } \\
\text { observational }\end{array}$ & Single-center PICU & 1,447 admissions & $\begin{array}{l}\text { Admission } \mathrm{PaO}_{2} \text { in } 50 \\
\mathrm{mmHg} \text { bands }\end{array}$ & $\begin{array}{l}\text { In-hospital } \\
\text { mortality }\end{array}$ & $\begin{array}{l}\text { Polynomial regression } \\
\text { with modified PIM-3 } \\
\text { based risk-adjustment }\end{array}$ & $\begin{array}{l}\text { U-shaped mortality curve; with I } \\
\text { mortality in } 101-200 \mathrm{~mm} \mathrm{Hg} \text { bands; } \\
\text { higher mortality in < } 50 \mathrm{mmHg} \text { and } \\
>350 \mathrm{mmHg} \text { bands } \\
\text { aOR for mortality of } 2.66 \mathrm{in} \\
\text { hyperoxemic }(250 \mathrm{mmHg} \text { ) group }\end{array}$ \\
\hline Peters et al. (38) & $\begin{array}{l}\text { Pilot open } \\
\text { randomized- } \\
\text { controlled } \\
\text { trial }\end{array}$ & $\begin{array}{l}\text { Multi-center (3 sites) } \\
\text { PICU }\end{array}$ & 117 admissions & $\begin{array}{l}\mathrm{SpO}_{2}>94 \% \text { vs. } \mathrm{SpO}_{2} \\
88-92 \%\end{array}$ & N/A (pilot study) & Descriptive statistics & $\begin{array}{l}\text { No difference in ICU mortality, } \\
\text { ventilator free days at day } 30 \text {, or ICU } \\
\text { length of stay }\end{array}$ \\
\hline Ramgopal et al. (39) & $\begin{array}{l}\text { Retrospective, } \\
\text { observational }\end{array}$ & Single-center PICU & 6,250 admissions & $\begin{array}{l}\text { Hyperoxemia ( } \geq 300 \mathrm{mmHg} \text { ) } \\
\text { at any time }\end{array}$ & $\begin{array}{l}\text { In-hospital } \\
\text { mortality }\end{array}$ & $\begin{array}{l}\text { Logistic regression } \\
\text { using adjusted PELOD, } \\
\text { use of ECMO, number } \\
\text { of } A B G \text { collected }\end{array}$ & $\begin{array}{l}\text { aOR for hyperoxemia } 1.78(95 \% \mathrm{Cl} \\
1.36-2.33) \text {; odds of mortality rising } \\
\text { with number of hyperoxemic } \mathrm{ABG}\end{array}$ \\
\hline Ramgopal et al. (40) & $\begin{array}{l}\text { Retrospective, } \\
\text { observational }\end{array}$ & Single-center PICU & 4,093 admissions & $\begin{array}{l}\text { Hyperoxemia }(\geq 300 \mathrm{mmHg}) \\
\text { and "extreme hyperoxemia" } \\
(\geq 550 \mathrm{mmHg})-6 \text { to }+6 \mathrm{~h} \text { of } \\
\text { PICU admission }\end{array}$ & $\begin{array}{l}\text { In-hospital } \\
\text { mortality }\end{array}$ & $\begin{array}{l}\text { Logistic regression } \\
\text { using adjusted } \\
\text { PRISM-IV }\end{array}$ & $\begin{array}{l}\text { Hyperoxemia not associated with } \\
\text { increased adjusted mortality risk (aOR } \\
1.38,95 \% \mathrm{Cl} 0.98-1.93 \text { ). "Extreme } \\
\text { hyperoxemia" associated with higher } \\
\text { aOR of mortality (aOR } 2.44,95 \% \mathrm{Cl} \\
1.32-4.50 \text { ) }\end{array}$ \\
\hline Pelletier et al. (41) & $\begin{array}{l}\text { Retrospective, } \\
\text { observational }\end{array}$ & $\begin{array}{l}\text { Multi-center (6 sites) } \\
\text { PICU }\end{array}$ & $\begin{array}{l}4,469 \text { admissions } \\
\text { requiring } \\
\text { mechanical } \\
\text { ventilation }\end{array}$ & $\begin{array}{l}\text { Maximum } \mathrm{PaO}_{2} \text { in } 100 \\
\mathrm{mmHg} \text { bands }\end{array}$ & $\begin{array}{l}\text { In-hospital } \\
\text { mortality }\end{array}$ & $\begin{array}{l}\text { Polynomial regression, } \\
\text { adjusted for } \\
\text { demographic variables } \\
\text { and clinical variables }\end{array}$ & $\begin{array}{l}\text { Maximum } \mathrm{PaO}_{2} \text { associated with } \\
\text { mortality (adjusted standardized } \\
\text { mortality ratio } 1.27,95 \% \mathrm{Cl} \\
1.23-1.32 \text { ) }\end{array}$ \\
\hline \multicolumn{8}{|l|}{ Post-cardiac arrest } \\
\hline Ferguson et al. (42) & $\begin{array}{l}\text { Retrospective, } \\
\text { observational }\end{array}$ & $\begin{array}{l}\text { Multicenter (33 sites), } \\
\text { post-cardiac arrest }\end{array}$ & $\begin{array}{l}1,875 \text { post-arrest } \\
\text { patients }\end{array}$ & $\begin{array}{l}\text { Hypoxia }(<60 \mathrm{mmHg}) \text { and } \\
\text { Hyperoxemia }(\geq 300 \mathrm{mmHg}) \\
\text { collected after PICU } \\
\text { physician evaluation to } 1 \mathrm{~h} \\
\text { after PICU admission }\end{array}$ & Mortality in PICU & $\begin{array}{l}\text { Polynomial regression, } \\
\text { adjusting for } \\
\text { demographics, site of } \\
\text { arrest, congenital } \\
\text { cardiac disease, } \\
\text { supportive therapies, } \\
\text { and PIM-2 }\end{array}$ & $\begin{array}{l}\text { Hyperoxia found in } 24 \% \text { of initial } A B G \\
\text { Hyperoxemia associated with } \\
\text { mortality (aOR 1.25; } 95 \% \\
\text { Cl 1.17-1.37) }\end{array}$ \\
\hline Del Castillo et al. (43) & $\begin{array}{l}\text { Prospective, } \\
\text { observational }\end{array}$ & $\begin{array}{l}\text { Multicenter, } \\
\text { post-cardiac arrest }\end{array}$ & $\begin{array}{l}\text { 223, post-arrest } \\
\text { patients }\end{array}$ & 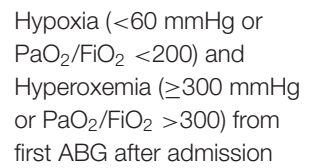 & $\begin{array}{l}\text { In-hospital } \\
\text { mortality }\end{array}$ & Chi-squared test & $\begin{array}{l}\text { Mortality with hyperoxia } 33 \% \text {, } \\
\text { hypoxemia } 29.8 \% \text {, and normoxemia } \\
35.8 \% \text {; not statistically significant ( } p \\
=0.16 \text { ) }\end{array}$ \\
\hline
\end{tabular}


TABLE 1 | Continued

\begin{tabular}{|c|c|c|c|c|c|c|c|}
\hline References & Study type & Population & Number & Predictor & Outcome & Analysis & Key findings \\
\hline $\begin{array}{l}\text { Guerra-Wallace et al. } \\
\text { (44) }\end{array}$ & $\begin{array}{l}\text { Retrospective, } \\
\text { observational }\end{array}$ & $\begin{array}{l}\text { Single center, } \\
\text { post-cardiac arrest }\end{array}$ & $\begin{array}{l}74 \text { post-arrest } \\
\text { patients }\end{array}$ & $\begin{array}{l}\text { Any hyperoxemia (>300 } \\
\mathrm{mmHg} \text { ) }\end{array}$ & 6-month mortality & Descriptive & $\begin{array}{l}38 \text { patients with at least one } \mathrm{PaO}_{2} \\
\text { >300 mmHg; no association with } \\
6 \text {-month mortality among patients } \\
\text { with hypoxemia or hyperoxemia }\end{array}$ \\
\hline van Zellem et al. (45) & $\begin{array}{l}\text { Retrospective, } \\
\text { observational }\end{array}$ & $\begin{array}{l}\text { Single center, } \\
\text { post-cardiac arrest; } \\
\text { receiving mild } \\
\text { therapeutic } \\
\text { hypothermia }\end{array}$ & $\begin{array}{l}200 \text { post-arrest } \\
\text { patients }\end{array}$ & $\begin{array}{l}>250 \mathrm{mmHg} \text { any time } \\
\text { following arrest; derived } \\
\text { from cutoff analysis }\end{array}$ & $\begin{array}{l}\text { In-hospital } \\
\text { mortality }\end{array}$ & $\begin{array}{l}\text { Logistic regression } \\
\text { adjusted for age, } \\
\text { gender, type of } \\
\text { resuscitation, location, } \\
\text { rhythm, } \mathrm{pH} \text {, lactate } \\
\text { Cumulative } \mathrm{PaO}_{2} \\
\text { analysis using } \mathrm{AUC} \\
\text { determined by } \\
\text { trapezoidal method }\end{array}$ & $\begin{array}{l}\text { Univariable analysis suggested } \\
\text { improved survival odds with } \\
\text { hyperoxemia (not found after } \\
\text { adjustment of confounders) } \\
\text { No association between duration of } \\
\text { cumulative } \mathrm{PaO}_{2} \mathrm{AUC} \text { and mortality }\end{array}$ \\
\hline \multicolumn{8}{|c|}{ Traumatic brain injury } \\
\hline Ramaiah et al. (46) & $\begin{array}{l}\text { Retrospective, } \\
\text { observational }\end{array}$ & Single center, post-TBI & 194 admissions & $\begin{array}{l}\text { Hypoxemia }(<60 \mathrm{mmHg}) \\
\text { Hyperoxemia } \\
(300-500 \mathrm{mmHg})\end{array}$ & $\begin{array}{l}\text { In-hospital } \\
\text { mortality }\end{array}$ & $\begin{array}{l}\text { Logistic regression } \\
\text { adjusted for age, injury } \\
\text { severity score }\end{array}$ & $\begin{array}{l}\text { Hyperoxemia associated with higher } \\
\text { odds to survival (aOR } 8.02,95 \% \mathrm{Cl} \\
1.73-37.10 \text { ) }\end{array}$ \\
\hline \multicolumn{8}{|c|}{ Extracorporeal membrane oxygenation } \\
\hline Cashen et al. (47) & $\begin{array}{l}\text { Retrospective, } \\
\text { observational }\end{array}$ & $\begin{array}{l}\text { Multi center ( } 8 \text { sites), } \\
\text { within } 48 \mathrm{~h} \text { of ECMO } \\
\text { cannulation }\end{array}$ & 484 admissions & Hyperoxemia (>200 mmHg) & $\begin{array}{l}\text { In-hospital } \\
\text { mortality }\end{array}$ & $\begin{array}{l}\text { Logistic regression, } \\
\text { adjusted for carbon } \\
\text { dioxide level, lactate, } \\
\text { diagnosis, and } \\
\text { pre-term status }\end{array}$ & $\begin{array}{l}\text { Lowest mortality in group with } \mathrm{PaO}_{2} \\
60-99 \mathrm{mmHg} \text {, stepwise increases } \\
\text { above } 100 \mathrm{mmHg} \\
\text { Hyperoxemia associated with } \\
\text { increased odds of in-hospital } \\
\text { mortality (OR } 1.03 \text { 95\% Cl 1.01-1.04 } \\
\text { for every } 10 \mathrm{mmHg} \text { ) }\end{array}$ \\
\hline
\end{tabular}

$A B G$, arterial blood gas; ECMO, extracorporeal membrane oxygenation; N/A, not applicable; PICU, pediatric intensive care unit; PIM, pediatric index of mortality; PRISM, pediatric risk of mortality. 
demonstrated increased patient mortality with $\mathrm{PaO}_{2}$ values above $300-400 \mathrm{mmHg}$, and one found this relationship only above $550 \mathrm{mmHg}$. Peters et al. conducted a pilot open randomizedcontrolled trial including 119 patients $>38$ weeks gestation and $<16$ years of age undergoing non-invasive or invasive mechanical ventilation (38). They randomized patients to target $\mathrm{SpO}_{2}>94 \%$ (liberal oxygen strategy) or $88-92 \%$ (conservative oxygen strategy). As it was a pilot study, there was no power calculation performed for clinical outcomes, which were available for $107 / 119$ patients. There was no significant difference in ICU mortality (4/53 vs. 4/54 liberal vs. conservative, respectively), ventilator-free days, or ICU length of stay (38).

Numa et al. performed a single-center retrospective database analysis of arterial blood gas values obtained within $1 \mathrm{~h}$ of ICU admission (37). They demonstrated a polynomial relationship between $\mathrm{PaO}_{2}$ and mortality both before and after adjustment for Pediatric Index of Mortality-3 scores: patients with a $\mathrm{PaO}_{2}$ of 301-350 had standardized mortality ratio of 1.18 compared to those with $\mathrm{PaO}_{2}$ 251-300. When incorporated in a model including other variables associated with mortality, patients with $\mathrm{PaO}_{2} \geq 250 \mathrm{mmHg}$ had an adjusted odds ratio (aOR) of mortality of 2.66. In a similar investigation, Raman et al. performed a single-center retrospective analysis of the relationship between $\mathrm{PaO}_{2}$ on pediatric ICU admission and mortality before and after adjustment for Pediatric Index of Mortality-2 scores (modified to remove the $\mathrm{PaO}_{2} / \mathrm{FiO}_{2}$ ratio) (36). They included all patients admitted to pediatric, neonatal, or cardiac intensive care units. They found that both unadjusted and adjusted mortality were lowest in patients with $\mathrm{PaO}_{2}$ values between 187 and $300 \mathrm{mmHg}$.

Ramgopal et al. conducted a single-center retrospective analysis of $\mathrm{PaO}_{2}$ values at any point during ICU admission, and found that a maximum $\mathrm{PaO}_{2} \geq 300 \mathrm{mmHg}$ was associated with increased mortality after adjustment for a modified Pediatric Logistic Organ Dysfunction-2 score (aOR 1.75 95\% confidence interval [CI] 1.33-2.29) (39). This study also suggested an exposure gradient: patients who had multiple $\mathrm{PaO}_{2}$ values $\geq 300$ $\mathrm{mmHg}$ had higher risk-adjusted mortality than those with only a single value in this range (odds ratio for one $\mathrm{PaO}_{2}$ value $\geq 300$ $\mathrm{mmHg} 1.47$ 95\% CI 1.05-2.08 compared to odds ratio for at least three $\mathrm{PaO}_{2}$ values $\geq 300 \mathrm{mmHg} 2.5395 \%$ CI 1.62-3.94). In a second study, Ramgopal et al. also examined $\mathrm{PaO}_{2}$ values in the $12 \mathrm{~h}$ surrounding PICU admission when adjusting for a modified Pediatric Risk of Mortality IV score (40). While this study found that $\mathrm{PaO}_{2} \geq 300 \mathrm{mmHg}$ was not significantly associated with riskadjusted mortality (OR $1.3895 \%$ CI $0.98-1.93$ ), a $\mathrm{PaO}_{2} \geq 550$ $\mathrm{mmHg}$ did reach the threshold of statistical significance (OR 2.44 95\% CI 1.32-4.50) (40). Given that the point estimate of this latter study was still suggestive of a relationship between $\mathrm{PaO}_{2}$ $\geq 300 \mathrm{mmHg}$ and risk-adjusted mortality, it is worth noting that a smaller sample size may have accounted for some of these differences: while the former study included 23,719 patients, the latter included a subset of fewer than $20 \%$ of those cases $(39,40)$.

Pelletier et al. performed a multicenter, mixed-diagnosis pediatric study examining the potential relationship between hyperoxemia and outcome (41). The authors performed a retrospective analysis of a federated electronic health record database from six large academic pediatric centers over 3 years $(48,49)$. Because the variables for previously-validated risk-adjustment models were not available for their cohort, they trained and validated a novel risk-adjustment model based on laboratory values, inotrope and vasopressor use, and demographic characteristics (c-statistic 0.86 [95\% CI $0.79-$ $0.92]$, area under the precision recall curve 0.39 , standardized mortality ratio 0.96 [95\% CI $0.75-1.23]$ ), then added $\mathrm{PaO}_{2}$ to the model to determine the effect (41). They found that maximum $\mathrm{PaO}_{2}$ values above $384 \mathrm{mmHg}$ within the first $72 \mathrm{~h}$ of ICU admission in mechanically ventilated children were associated with increased risk-adjusted mortality (41). This finding was stable in sensitivity analyses excluding children with chronic complex cardiovascular conditions (50), those with traumatic brain injury and carbon monoxide poisoning, and children presenting after cardiac arrest (41). The findings were also stable in a sensitivity analysis examining $\mathrm{PaO}_{2}$ values at any time during admission (41). However, when the cohort was narrowed to examine only $\mathrm{PaO}_{2}$ values within $24 \mathrm{~h}$ of admission, a higher threshold of hyperoxemia $(\geq 486 \mathrm{mmHg}$ ) was associated with risk-adjusted mortality.

\section{Pediatric ICU Patients Admitted After Cardiac Arrest}

There are currently four studies evaluating the relationship between $\mathrm{PaO}_{2} \geq 300 \mathrm{mmHg}$ and mortality in pediatric ICU patients admitted after cardiac arrest. Of these, one identified a significant relationship between hyperoxemia and mortality after adjustment for confounders, and the other three did not (4245). Ferguson et al. first performed a retrospective observational multicenter database study of 1,875 children $\leq 16$ years old admitted to a pediatric ICU following cardiac arrest (42). They found that $\mathrm{PaO}_{2}$ on the first blood gas obtained within $1 \mathrm{~h}$ of arrival to the pediatric ICU had a non-linear association with mortality. After adjustment for age, sex, arrest location, and Pediatric Index of Mortality-2 scores, they noted that the optimal first $\mathrm{PaO}_{2}$ was $60-75 \mathrm{mmHg}$, and that mortality rose both above and below this value. At the extremes, a $\mathrm{PaO}_{2}$ of $23 \mathrm{mmHg}$ was associated with an increased aOR of mortality of 1.92 (95\% CI $1.80-2.21)$, and a $\mathrm{PaO}_{2}$ value of $600 \mathrm{mmHg}$ was associated with an increased aOR of mortality (1.25; 95\% CI 1.17-1.37).

Del Castillo et al. performed a retrospective multicenter study of 223 patients aged 1 month to 18 years admitted after cardiac arrest in which they evaluated the relationship between arterial blood gas values immediately post-resuscitation and $24 \mathrm{~h}$ later with mortality. They found increased mortality in patients with $\mathrm{PaO}_{2} \geq 300 \mathrm{mmHg}$ (52.6\%) vs. those with $\mathrm{PaO}_{2}<60 \mathrm{mmHg}$ (42.4\%) or those with $\mathrm{PaO}_{2}$ values $\geq 60 \mathrm{mmHg}$ and $<300$ $\mathrm{mmHg}(40.7 \%)$, but the difference was not statistically significant $(p=0.61)$.

Guerra-Wallace et al. conducted a single-center retrospective chart review of 74 patients admitted to a pediatric ICU after cardiac arrest (44). Their study was notable for including the highest and lowest $\mathrm{PaO}_{2}$ of patients within the first $24 \mathrm{~h}$ after admission, and for excluding patients who died within $48 \mathrm{~h}$ of admission. They found no association between $\mathrm{PaO}_{2}$ values $<60$ $\mathrm{mmHg}$ or $\geq 300 \mathrm{mmHg}$ and unadjusted mortality at 6 months 
(44). van Zellem et al. conducted a single-center retrospective study of patients $>28$ days to $<18$ years old admitted to a pediatric ICU after cardiac arrest (45). They did not find a significant association between $\mathrm{PaO}_{2}$ values $\geq 300 \mathrm{mmHg}$ and mortality before or after adjustment for confounders. However, in the subset of patients concomitantly undergoing moderate therapeutic hypothermia they found an association between higher cumulative $\mathrm{PaO}_{2}$ values in the first $24 \mathrm{~h}$ and survival (45).

\section{Pediatric ICU Patients Admitted With Severe Traumatic Brain Injury}

A single study by Ramaiah et al. retrospectively evaluated the association between $\mathrm{PaO}_{2}$ values and mortality in patients age $\leq 14$ years admitted to a single pediatric ICU (46). In contrast to the majority of other studies, they found that admission $\mathrm{PaO}_{2}$ 300-500 mmHg was associated with increased survival to discharge (aOR 8.02 95\% CI 1.73-37.10) (46). While not included in their multivariable model, the authors found that $\mathrm{PaO}_{2}$ values $<100 \mathrm{mmHg}$ or $>500 \mathrm{mmHg}$ were associated with worse survival (46). In addition to being notable as the only study to find a favorable association between $\mathrm{PaO}_{2}$ values $\geq 300 \mathrm{mmHg}$ and survival to discharge, this study is also notable for its effect size (46). No other study including $<1,000$ admissions found any significant effect of hyperoxemia, albeit in different populations (46). While the authors did not analyze collinearity between $\mathrm{PaO}_{2}$ values and chest trauma in this cohort, significantly fewer survivors than non-survivors had concomitant chest trauma [39/162 [24.1\%] vs. $13 / 32[40.6 \%], p=0.05 ;(46)]$. In a separate retrospective review of traumatic brain injury, Michaud et al. secondarily found that $\mathrm{PaO}_{2}$ and chest trauma were collinear in their population, and that hypoxemia and chest trauma were associated with poor outcome in traumatic brain injury (51). Thus, it remains unclear whether higher $\mathrm{PaO}_{2}$ values are beneficial in traumatic brain injury, or whether these values are confounded by polytrauma.

\section{Pediatric ICU Patients on Extracorporeal Membrane Oxygenation}

Cashen et al. conducted a multicenter, retrospective database study of 484 patients age $<19$ years treated with extracorporeal membrane oxygenation (ECMO) for heterogenous diagnoses (47). They analyzed arterial blood gas data obtained within $48 \mathrm{~h}$ of ECMO cannulation. They defined hyperoxia as $\mathrm{PaO}_{2}>200$ mmHg. They found that patients with a maximal $\mathrm{PaO}_{2} 60-$ $99 \mathrm{mmHg}$ had the lowest mortality. Mortality was higher for patients with a maximal $\mathrm{PaO}_{2}<60 \mathrm{mmHg}$, and there were stepwise increases in mortality for every $100 \mathrm{mmHg}$ increase above $100 \mathrm{mmHg}$. Patients with a maximum $\mathrm{PaO}_{2}>200 \mathrm{mmHg}$ had substantially higher in-hospital mortality than those that did not (167/331 [50.5\%] vs. 48/153 [31.4\%]), respectively. In multivariable logistic regression accounting for lactate, diagnosis, and age, every $10 \mathrm{mmHg}$ increase in $\mathrm{PaO}_{2}$ was associated with an increased odds of mortality (OR 1.03 95\% CI 1.011.04). However, the hyperoxia group was notable in that it had a significantly higher proportions of patients with a cardiac indication for ECMO (48.9 vs. $24.8 \%$ ), ECPR (16.0 vs. $10.5 \%)$, and venoarterial cannulation ( 92.1 vs. $75.2 \%)$.

\section{Areas of Controversy in the Pediatric Literature}

Existing literature examining the relationship between hyperoxemia and outcomes among critically ill children is limited and predominantly observational. Additionally, the threshold at which hyperoxemia may result in harm is unclear. Several pediatric studies support the idea of harm beginning at $\sim 300 \mathrm{mmHg}$, but no study $<1,000$ patients has demonstrated harm (43-46), and one study only showed a significant association between $\mathrm{PaO}_{2} \geq 550 \mathrm{mmHg}$ and mortality (40). It is also interesting to consider whether $\mathrm{PaO}_{2}$ is the right metric for oxygen toxicity at all; because excess oxygen is known to act as a local pulmonary mitochondrial toxin $(4,17,18)$ as well as a systemic inflammatory mediator $(4,19)$, it may well be that the relationship between $\mathrm{FiO}_{2}$ and mortality is much more important than the relationship between $\mathrm{PaO}_{2}$ and mortality.

Additionally, given their retrospective nature, all of the current pediatric studies are vulnerable to confounding by indication. For example, it may be that patients with high $\mathrm{PaO}_{2}$ values merely represent more gravely ill patients treated with high $\mathrm{FiO}_{2}$ as part of resuscitation bundles. As such, hyperoxemia may be associated with illness severity but not causative of clinically meaningful organ dysfunction. Expert opinion has queried whether hyperoxemia may be a spurious marker of death by neurological criteria as apnea testing is conventionally performed with an $\mathrm{FiO}_{2} \quad 1.0$ or evaluation for organ transplantation in moribund patients (36). However, several of the above studies support an association that would not be influenced by assessments for neurological death. Two studies evaluated $\mathrm{PaO}_{2}$ values within the first 6-24 h after admission $(37,39)$, and several evaluated $\mathrm{PaO}_{2}$ values either immediately on admission, or within $1 \mathrm{~h}(34,45,46)$. All of these studies found that hyperoxemia was associated with an increase in mortality, albeit at different threshold $\mathrm{PaO}_{2}$ values.

Given that there is likely to be little clinical benefit to prolonged periods of high $\mathrm{FiO}_{2}$ exposure, and given the array of preclinical and clinical studies suggestive of possible harm $(4,14-21,52-56)$, this question is unlikely to be answered directly in pediatric randomized controlled trials or prospective studies. It is difficult to imagine that there is clinical equipoise to randomize children to a target $\mathrm{PaO}_{2}$ of $\geq 300 \mathrm{mmHg}$, except perhaps in the specific situation of severe traumatic brain injury (43). Larger trials evaluating conservative oxygen administration strategies and targets compared to usual care are more likely to receive support. Recognizing the potential harm caused by hyperoxemia, the American Heart Association advocates a target oxygen saturation of $94-99 \%$ in the post-resuscitation setting $(48,57)(p 4)$. As learning health systems evolve to become more efficient with patient identification, clinical trial enrollment and data collection, there may be an opportunity to study oxygen delivery strategies among critically ill children with a prospective, randomized design that would otherwise have been deemed infeasible due to costs. 


\section{CONCLUSION}

Of the twelve pediatric studies evaluating the relationship between $\mathrm{PaO}_{2}$ and mortality, seven found a potentially harmful association between hyperoxemia and mortality. Notably, the five studies that did not find such an effect had substantially smaller sample sizes. The relationship between $\mathrm{PaO}_{2}$ values and mortality in the pediatric ICU setting appears to be polynomial ("u-shaped"), with both hypoxemia and hyperoxemia associated with increased mortality. Several studies demonstrated that this association persisted after adjustment for demographics and severity of illness. The exact value at which hyperoxemia is potentially harmful is unclear but is likely between 250 and 400 $\mathrm{mmHg}$. These studies reinforce preclinical and healthy volunteer studies that demonstrate a potentially deleterious effect of excess oxygen therapy. The single exception to this trend is in traumatic brain injury patients, where a single small study demonstrated a favorable association between $\mathrm{PaO}_{2}$ values $300-500 \mathrm{mmHg}$

\section{REFERENCES}

1. Haldane JS. The therapeutic administration of oxygen. $\mathrm{Br} \mathrm{Med} J$. (1917) 1:181-3. doi: 10.1136/bmj.1.2928.181

2. Barbateskovic M, Schjørring OL, Russo Krauss S, Jakobsen JC, Meyhoff CS, Dahl RM, et al. Supplemental oxygen for adults admitted to the intensive care unit. Cochrane Database Syst Rev. (2019). 2019:CD012631. doi: 10.1002/14651858.CD012631.pub2

3. Sokuri P, Heikkilä P, Korppi M. National high-flow nasal cannula and bronchiolitis survey highlights need for further research and evidencebased guidelines. Acta Paediatr. (2017) 106:1998-2003. doi: 10.1111/apa. 13964

4. Kallet RH, Matthay MA. Hyperoxic acute lung injury. Respir Care. (2013) 58:123-41. doi: 10.4187/respcare.01963

5. Ramji S, Ahuja S, Thirupuram S, Rootwelt T, Rooth G, Saugstad OD. Resuscitation of asphyxic newborn infants with room air or $100 \%$ oxygen. Pediatr Res. (1993) 34:809-12. doi: 10.1203/00006450-199312000-00023

6. Saugstad OD. Mechanisms of tissue injury by oxygen radicals: implications for neonatal disease. Acta Paediatr. (1996) 85:14. doi: 10.1111/j.1651-2227.1996.tb13880.x

7. Kattwinkel J, Perlman JM, Aziz K, Colby C, Fairchild K, Gallagher J, et al., Part 15: Neonatal Resuscitation. Circulation. (2010) 122:S90919. doi: 10.1161/CIRCULATIONAHA.110.971119

8. Andresen JH, Saugstad OD. Oxygen metabolism and oxygenation of the newborn. Semin Fetal Neonatal Med. (2020) 25:101078. doi: $10.1016 /$ j.siny.2020.101078

9. Saugstad OD. Resuscitation of newborn infants: from oxygen to room air. Lancet. (2010) 376:1970-1. doi: 10.1016/S0140-6736(10)60543-0

10. Kayton A, Timoney P, Vargo L, Perez JA. A review of oxygen physiology and appropriate management of oxygen levels in premature neonates. $A d v$ Neonatal Care. (2018) 18:98-104. doi: 10.1097/ANC.0000000000000434

11. Kim E, Nguyen M. Oxygen therapy for neonatal resuscitation in the delivery room. NeoReviews. (2019) 20:e500-12. doi: 10.1542/neo.20-9-e500

12. Vento M, Saugstad OD. Oxygen as a therapeutic agent in neonatology: a comprehensive approach. Semin Fetal Neonatal Med. (2010) 15:185. doi: 10.1016/j.siny.2010.04.002

13. Clark JM, Lambertsen CJ. Pulmonary oxygen toxicity: a review. Pharmacol Rev. (1971) 23:37-3.

14. Murphy MP. How mitochondria produce reactive oxygen species. Biochem J. (2009) 417:1-13. doi: 10.1042/BJ20081386

15. Auten RL, Davis JM. Oxygen toxicity and reactive oxygen species: the devil is in the details. Pediatr Res. (2009) 66:1217. doi: 10.1203/PDR.0b013e3181a9eafb and mortality. It remains unclear whether hyperoxemia causes clinical harm, or is a marker of illness severity. However, in the absence of a specific indication, pediatric providers should be prudent with the use of oxygen therapy and avoid $\mathrm{PaO}_{2}$ values $\geq 300$.

\section{AUTHOR CONTRIBUTIONS}

JP wrote the first draft of the manuscript. SR wrote the first draft of the table. All authors critically revised the manuscript. All authors have reviewed the final version, agreed upon submission, and agree to be accountable for the content of the work.

\section{FUNDING}

JP was funded by 5T32HD040686-20. CH was funded by 1K23HD099331-01A1. SR was funded by K12 PEDSnet Scholar.

16. Johnson F, Giulivi C. Superoxide dismutases and their impact upon human health. Mol Aspects Med. (2005) 26:340-52. doi: 10.1016/j.mam.2005.07.006

17. Brueckl C, Kaestle S, Kerem A, Habazettl H, Krombach F, Kuppe H, et al. Hyperoxia-induced reactive oxygen species formation in pulmonary capillary endothelial cells in situ. Am J Respir Cell Mol Biol. (2006) 34:45363. doi: $10.1165 / \mathrm{rcmb}$.2005-0223OC

18. Turrens JF. Mitochondrial formation of reactive oxygen species. J Physiol. (2003) 552:335-44. doi: 10.1113/jphysiol.2003.049478

19. Dias-Freitas F, Metelo-Coimbra C, Roncon-Albuquerque R. Molecular mechanisms underlying hyperoxia acute lung injury. Respir Med. (2016) 119:23-8. doi: 10.1016/j.rmed.2016.08.010

20. Hartnett ME, Lane RH. Effects of oxygen on the development and severity of retinopathy of prematurity. J AAPOS. (2013) 17:229-34. doi: 10.1016/j.jaapos.2012.12.155

21. O'Donovan DJ, Fernandes CJ. Free radicals and diseases in premature infants. Antioxid Redox Signal. (2004) 6:169-76. doi: 10.1089/152308604771978471

22. Naumburg E, Bellocco R, Cnattingius S, Jonzon A, Ekbom A. Supplementary oxygen and risk of childhood lymphatic leukaemia. Acta Paediatr. (2002) 91:1328-33. doi: 10.1111/j.1651-2227.2002.tb02829.x

23. Spector LG, Klebanoff MA, Feusner JH, Georgieff MK, Ross JA. Childhood cancer following neonatal oxygen supplementation. J Pediatr. (2005) 147:2731. doi: $10.1016 /$ j.jpeds.2005.03.008

24. Elmer J, Scutella M, Pullalarevu R, Wang B, Trzeciak S, Rosario-Rivera BL, et al. The association between hyperoxia and patient outcomes after cardiac arrest: analysis of a high-resolution database. Intensive Care Med. (2016) 41:49-57. doi: 10.1007/s00134-014-3555-6

25. Johnson NJ, Dodampahala K, Rosselot B, Perman SM, Mikkelsen ME, Goyal $\mathrm{M}$, et al. The association between arterial oxygen tension and neurological outcome after cardiac arrest. Ther Hypothermia Temp Manag. (2017) 7:3641. doi: 10.1089/ther.2016.0015

26. Kilgannon JH, Jones AE, Shapiro NI, Angelos MG, Milcarek B, Hunter $\mathrm{K}$, et al. Association between arterial hyperoxia following resuscitation from cardiac arrest and in-hospital mortality. JAMA. (2010) 303:216571. doi: 10.1001/jama.2010.707

27. Roberts BW, Kilgannon JH, Hunter BR, Puskarich MA, Pierce L, Donnino $\mathrm{M}$, et al. Association between early hyperoxia exposure after resuscitation from cardiac arrest and neurological disability: prospective multicenter protocol-directed cohort study. Circulation. (2018) 137:211424. doi: 10.1161/CIRCULATIONAHA.117.032054

28. Chu DK, Kim LH-Y, Young PJ, Zamiri N, Almenawer SA, Jaeschke R, et al. Mortality and morbidity in acutely ill adults treated with liberal versus conservative oxygen therapy (IOTA): a systematic review and meta-analysis. Lancet. (2018) 391:1693-705. doi: 10.1016/S0140-6736(18)30479-3 
29. Shi S, Qi Z, Ma Q, Pan R, Timmins GS, Zhao Y, et al. Normobaric hyperoxia reduces blood occludin fragments in rats and patients with acute ischemic stroke. Stroke. (2017) 48:2848-54. doi: 10.1161/STROKEAHA.117.017713

30. Girardis M, Busani S, Damiani E, Donati A, Rinaldi L, Marudi A, et al. Effect of conservative vs. conventional oxygen therapy on mortality among patients in an intensive care unit: the oxygen-ICU randomized clinical trial. JAMA. (2016) 316:1583-9. doi: 10.1001/jama.2016.11993

31. Panwar R, Hardie M, Bellomo R, Barrot L, Eastwood GM, Young PJ, et al. Conservative versus liberal oxygenation targets for mechanically ventilated patients. A pilot multicenter randomized controlled trial. Am J Respir Crit Care Med. (2016) 193:43-51. doi: 10.1164/rccm.201505-1019OC

32. The ICU-ROX Investigators the Australian New Zealand Intensive Care Society Clinical Trials Group. Conservative oxygen therapy during mechanical ventilation in the ICU. $N$ Engl J Med. (2020) 382:989-98. doi: 10.1056/NEJMoa1903297

33. Young PJ, Beasley RW, Capellier G, Eastwood GM, Webb SAR, ANZICS Clinical Trials Group and the George Institute for Global Health. Oxygenation targets, monitoring in the critically ill: a point prevalence study of clinical practice in Australia and New Zealand. Crit Care Resusc J Australas Acad Crit Care Med. (2015) 17:202-7.

34. Helmerhorst HJ, Schultz MJ, van der Voort PH, Bosman RJ, Juffermans NP, de Jonge E, et al. Self-reported attitudes versus actual practice of oxygen therapy by ICU physicians and nurses. Ann Intensive Care. (2014) 4:23. doi: 10.1186/s13613-014-0023-y

35. Panwar R, Capellier G, Schmutz N, Davies A, Cooper DJ, Bailey $\mathrm{M}$, et al. Current oxygenation practice in ventilated patientsan observational cohort study. Anaesth Intensive Care. (2013) 41:505-14. doi: 10.1177/0310057X1304100412

36. Raman S, Prince NJ, Hoskote A, Ray S, Peters MJ. Admission $\mathrm{Pao}_{2}$ and mortality in critically ill children: a cohort study and systematic review. Pediatr Crit Care Med. (2016) 17:e444-50. doi: 10.1097/PCC.0000000000000905

37. Numa A, Aneja H, Awad J, Ravindranathan H, Singh P, Swil $\mathrm{K}$, et al. Admission hyperoxia is a risk factor for mortality in pediatric intensive care. Pediatr Crit Care Med. (2018) 19:699-704. doi: 10.1097/PCC.0000000000001630

38. Peters MJ, Jones GAL, Wiley D, Wulff J, Ramnarayan P, Ray S, et al. Conservative versus liberal oxygenation targets in critically ill children: the randomised multiple-centre pilot Oxy-PICU trial. Intensive Care Med. (2018) 44:1240-8. doi: 10.1007/s00134-018-5232-7

39. Ramgopal S, Dezfulian C, Hickey RW, Au AK, Venkataraman S, Clark $\mathrm{RSB}$, et al. Association of severe hyperoxemia events and mortality among patients admitted to a pediatric intensive care unit. JAMA Netw Open. (2019) 2:e199812. doi: 10.1001/jamanetworkopen.2019.9812

40. Ramgopal S, Dezfulian C, Hickey RW, Au AK, Venkataraman S, Clark RSB, et al. Early hyperoxemia and outcome among critically ill children: Pediatr Crit Care Med. (2020) 21:e129-32. doi: 10.1097/PCC.0000000000 002203

41. Pelletier JH, Ramgopal S, Au AK, Clark RSB, Horvat CM. Maximum $\mathrm{PaO}_{2}$ in the first 72 hours of intensive care is associated with risk-adjusted mortality in pediatric patients undergoing mechanical ventilation. Crit Care Explor. (2020) 2:e0186. doi: 10.1097/CCE.0000000000000186

42. Ferguson LP, Durward A, Tibby SM. Relationship between arterial partial oxygen pressure after resuscitation from cardiac arrest and mortality in children. Circulation. (2012) 126:335-42. doi: 10.1161/CIRCULATIONAHA.111. 085100

43. Del Castillo J, López-Herce J, Matamoros M, Cañadas S, Rodriguez-Calvo A, Cechetti C, et al. Hyperoxia, hypocapnia and hypercapnia as outcome factors after cardiac arrest in children. Resuscitation. (2012) 83:1456-61. doi: 10.1016/j.resuscitation.2012. 07.019
44. Guerra-Wallace MM, Casey FL, Bell MJ, Fink EL, Hickey RW. Hyperoxia and hypoxia in children resuscitated from cardiac arrest. Pediatr Crit Care Med. (2013) 14:e143-8. doi: 10.1097/PCC.0b013e3182720440

45. van Zellem L, de Jonge R, van Rosmalen J, Reiss I, Tibboel D, Buysse C. High cumulative oxygen levels are associated with improved survival of children treated with mild therapeutic hypothermia after cardiac arrest. Resuscitation. (2015) 90:150-7. doi: 10.1016/j.resuscitation.2014.12.013

46. Ramaiah VK, Sharma D, Ma L, Prathep S, Hoffman NG, Vavilala MS Admission oxygenation and ventilation parameters associated with discharge survival in severe pediatric traumatic brain injury. Childs Nerv Syst. (2013) 29:629-34. doi: 10.1007/s00381-012-1984-5

47. Cashen K, Reeder R, Dalton HJ, Berg RA, Shanley TP, Newth CJL, et al. Hyperoxia and hypocapnia during pediatric extracorporeal membrane oxygenation: associations with complications, mortality, and functional status among survivors. Pediatr Crit Care Med. (2018) 19:245-53. doi: 10.1097/PCC.0000000000001439

48. Narus SP, Srivastava R, Gouripeddi R, Livne OE, Mo P, Bickel JP, et al. Federating clinical data from six pediatric hospitals: process and initial results from the PHIS+ Consortium. AMIA Annu Symp Proc. (2011) 2011:994-1003.

49. PHIS. Available online at: https://www.childrenshospitals.org/phis (accessed October 23, 2019).

50. Feudtner C, Feinstein JA, Zhong W, Hall M, Dai D. Pediatric complex chronic conditions classification system version 2: updated for ICD-10 and complex medical technology dependence and transplantation. BMC Pediatr. (2014) 14:199. doi: 10.1186/1471-2431-14-199

51. Michaud LJ, Rivara FP, Grady MS, Reay DT. Predictors of survival and severity of disability after severe brain injury in children. Neurosurgery. (1992) 31:254-64. doi: 10.1227/00006123-199208000-00010

52. Wang X-X, Sha X-L, Li Y-L, Li C-L, Chen S-H, Wang J-J, et al. Lung injury induced by short-term mechanical ventilation with hyperoxia and its mitigation by deferoxamine in rats. BMC Anesthesiol. (2020) 20:188. doi: 10.1186/s12871-020-01089-5

53. Kafer E. Pulmonary oxygen toxicity: a review of the evidence for acute and chronic oxygen toxicity in man. Br J Anaesth. (1971) 43:68795. doi: 10.1093/bja/43.7.687

54. Comroe JH, Dripps RD, Dumke PR, Deming M. Oxygen toxicity: the effect of inhalation of high concentrations of oxygen for twenty-four hours on normal men at sea level and at a simulated altitude of 18,000 feet. J Am Med Assoc. (1945) 128:710-7. doi: 10.1001/jama.1945.02860270012004

55. Crapo JD. Morphologic changes in pulmonary oxygen toxicity. Annu Rev Physiol. (1986) 48:721-31. doi: 10.1146/annurev.ph.48.030186.003445

56. Reinhart K, Bloos F, König F, Bredle D, Hannemann L. Reversible decrease of oxygen consumption by hyperoxia. Chest. (1991) 99:6904. doi: 10.1378/chest.99.3.690

57. Topjian AA, Raymond TT, Atkins D, Chan M, Duff JP, Joyner BL, et al. Part 4: pediatric basic and advanced life support: 2020 American Heart Association Guidelines for cardiopulmonary resuscitation and emergency cardiovascular care. Circulation. (2020) 142:S469-523. doi: 10.1161/CIR.00000000000 00901

Conflict of Interest: The authors declare that the research was conducted in the absence of any commercial or financial relationships that could be construed as a potential conflict of interest.

Copyright (C) 2021 Pelletier, Ramgopal and Horvat. This is an open-access article distributed under the terms of the Creative Commons Attribution License (CC BY). The use, distribution or reproduction in other forums is permitted, provided the original author(s) and the copyright owner(s) are credited and that the original publication in this journal is cited, in accordance with accepted academic practice. No use, distribution or reproduction is permitted which does not comply with these terms. 